\title{
Between norms, facts and stereotypes : the place of culture and ethnicity in Belgian and French family justice
}

\begin{abstract}
Based on extensive empirical fieldworks conducted in Belgian and French family justice courtrooms in order to explain how culture and ethnicity are processed and understood in the daily reasoning and assumptions of legal professionals, this chapter analyzes different forms in which culture and ethnicity are framed in family law cases. Understanding how and along which dimensions these elements do vary in judicial reasoning constitutes the preliminary but necessary step before assessing the need of cultural expertise as such. In this attempt, we shed light on a scope of variations between complex and non-deterministic models of culture consistent with contemporary anthropology literature - and more simplistic ones, in which culture and identity are conceived as fixed realities. Throughout this path between norms, facts and stereotypes, we illustrate not only the multiplicity and complexity of forms which cultural elements can take in the exercise of family justice, but also the risks that some significances may carry with them and the urgent need to improve more fluid and dispassionate conceptions of cultural diversity before developing "cultural expertise" as such, an expertise that could otherwise reinforce stereotypical and fixed views of "cultures".
\end{abstract}

\section{Keywords \\ Culture, ethnicity, judicial reasoning, family justice, families with migrant background}

\author{
Caroline Simon, Barbara Truffin, Anne Wyvekens
}

\section{Introduction}

In the contemporary context of broader diversification of ethno-cultural backgrounds and migration trajectories in European societies, the question of how culture and ethnicity enter the courtrooms still remains empirically under-researched and lacks theoretical systematization (but see Bouillier 2011, D'hondt 2010, 2009, D'hondt \& Beyens 2004, Petintseva 2016, Simon 2015, Simon \&Truffin 2016, Terrio 2009, van Rossum 2010, van Rossum \& Jansen Fredriksen 2014, van Rossum \& van den Hoven 2016, Wyvekens 2017, 2016, 2014 ). Offering more detailed and nuanced pictures than the narratives of incompatible values increasingly disseminated through public debates is an urgent need socio-legal studies should contribute to meet. More specifically for us, seeking to explain how culture and ethnicity are processed and understood in the daily reasoning and assumptions of legal professionals constitutes the first step towards this aim.

Praxeological approaches of state justice stand as an important starting point in this direction. Indeed, this growing body of studies allows to look at the judicial activities as made of mundane reasoning aligned with normative aspects of the legal provisions professionals are in charge to interpret and apply (Colemans 2015, Dupret 2010, 2007, 2006, Travers 2001). This theoretical angle is particularly relevant when assessing the role culture and ethnicity play in judicial reasoning in Belgium and France precisely because, in these countries as in many other continental legal systems, neither one nor the other are part of formal legal provision - if we set aside the formal interdiction contained in anti-discrimination regulation. Culture and ethnicity 
remain therefore unstable, if not elusive, dimensions of judicial reasoning infused by fluctuant background representations, categorizations and expectations. This theoretical positioning explains why we have chosen to focus more on this fundamental aspect than to discuss cultural expertise in our contribution to a book however explicitly dedicated to the latter. Understanding how and along which dimensions these background representations and expectations do vary in judicial reasoning is the core question we want to contribute to as a preliminary but necessary step. What are the conceptions of culture and ethnicity which are mobilized by Belgian and French judges in their daily work and to which extent do lawyers and social scientists operate with similar concepts?

Another reason for this choice is that, to the best of our knowledge, the very few "cultural expertise" reports produced for French and Belgian courtrooms do not really allow to understand what culture and ethnicity stand for in the individual responsibility assessments operated by the courts. Bluntly put, it is difficult to identify in those rare cases of expertise a "special knowledge that enables socio-legal scholars, or, more generally speaking, cultural mediators - the so-called cultural brokers -, to locate and describe relevant facts in light of the particular background of the claimants and litigants and for the use of the court" (Holden 2013, 2 ). Whether the crime has a cultural or religious explanation or not, as it was asked in an honor killing case which occurred in a Pakistani family some years ago in Belgium, can be a laconic and a fuzzy mandate for the expert. In this case, a young woman had been killed by her brother whereas she was dating a Belgian man, wanting to marry him. The parents of the girl had agreed on the murder or even ordered it. A "cultural expert" - who was actually a political scientist specialized in international relations and Pakistan - was required by the examining magistrate and asked "to peruse the whole file; to describe the issues of forced marriages, violence against women and honor killings in the Pakistani community, to confront the results of research to the content of the case; and to possibly give further information about the religious norms that could have played a role". Here, the way of addressing the question of religious norm is related with the difficulty to translate a non-deterministic definition of culture or religion into legal reasoning and procedures. We will come back on this later.

After some explanations on the analytical status we give to culture and ethnicity and why we have chosen to explore the field of family justice, we give more information on the conditions of our fieldworks in family justice courtrooms in Belgium and France; this being explained the chapter proceeds to review the different forms in which culture and ethnicity are framed in the courtrooms and in the practical reasoning of the judges in Belgian and French family justice: between norms, facts and stereotypes.

\section{Culture, ethnicity and family justice}

When they address cultural dimensions, anthropologists rely on complex configurations of facts articulated in non-simplistic causal ways with social norms (Cuche 2016, Dupret 2007, Cowan 2006, Cowan 2006, Cowan, Dembour \& Wilson 2001, Brumann 1999) but, of course, other conceptions of culture and ethnic identity do operate in social worlds, especially through the background expectations, categorizations and representations at work in social interactions. Because conceptions of culture and ethnicity vary in mundane representations, expectations and categorizations as much as they are susceptible to do in practical reasoning of legal professionals, we set the expected scope of variations between complex and non-deterministic models - consistent with contemporary anthropology literature - and more simplistic ones, in which culture and identity are conceived as fixed realities precipitating simple and causal relationships between social norms and facts. 
Legal professionals are not by nature resistant to the first model but as rightly put by Anthony Good, "it seems generally agreed that there are basic differences between how lawyers and social scientists think" (Good 2015, 430) and these differences can impact on how ethnicity and culture are used and apprehended in the courtrooms. As we shall see, in our researches we pay specific attention to the ways relationships between facts and norms are posited when cultural or ethnic dimensions are referred throughout the interactions in the courtrooms, because this articulation is at the core of legal theory and practices. Generally speaking, legal models of articulation of facts and rules are 'technically' and institutionally driven. Cowan, Dembour \& Wilson (2001) among other authors highlight the existence of an intrinsic tension in the activities of public institutions which formulate abstract and general rules, impermeable to ethno-cultural diversity, and their applications to concrete and particular cases. Judicial activities offer a paradigmatic illustration of this tension: what is to judge if not to apply general and abstract rules to an individual case?

Our choice to focus on family justice hearings and cases brought to courts by families with a migrant background is related with the changing importance of the articulation of norms and facts in legal reasoning in this field but also to the fact that families with a migrant background massively resort to state justice. Family justice offers a field especially interesting to investigate because of the progressive and recent changes family law has undergone in most European countries. These recent historical developments of family law towards a specific model of democratization of conjugal relationships and parenthood have different outcomes which all delineate family justice as a transformative field in which the scope of meanings and representations attached to culture and ethnicity are theoretically opened with a decreasing importance of standardized norms and adjudication activities.

Firstly, it goes hand in hand with a transformation of the judges' role when dealing with family matters; when they are to intervene into conjugal or children-care related conflicts within the scope designed by civil codes, it is less and less according to explicit standards and values consecrated by legislative dispositions. They thus enter the field of conjugal conflicts with the legal mandate to help and consecrate agreements between parents, and state regulation of the "private" sphere is then deeply reshaped (Ronfani 1997, Théry 1998, Cardia-Vonèche \& Bastard 2005). Moreover, since civil codes presume that spouses and parents are equals, they provide few standards in order to evaluate if mutual reproaches and claims are or not "acceptable" when disagreements occur.

Secondly, legislative primacy given to private agreements should allow, at least theoretically, state law and justice to accommodate all sorts of family structures, values and factual organizations. Legal commentators have generally praised such a turning point and predicted that family law was to become more pluralistic (Roussel 1989, Meulders-Klein \& Théry 1993, de Singly 2010, Roy 2011). In a sense, taking into consideration precise elements of the backgrounds of the litigants and/or of the children has become a constitutive part of the judicial function in the field of family justice as remodeled during the last decades.

More often than not, what should or could be labeled as "cultural" remains unclear and uneasy both for law professionals and for the litigants. This was especially significant in the preliminary interviews Anne Wyvekens conducted with judges in Belgium as in France (Wyvekens 2013, 141-142). When asked explicitly about cultural diversity, they had several forms of "no-answer", which manifested their uneasiness. Some of them answered that the question was not a frequent one; others considered that the cultural issue was much less important than the social one; and another group of judges actually just talked about something 
else: for instance, the lack of diversity among judges - which is obvious in France -, or a list of cases with an international dimension, like human beings trafficking, drugs trafficking, etc.

One of the reasons some judges gave for their embarrassment about the issues of culture and ethnicity is their lack of knowledge, putting forward the little training they get on these issues. In France, the political context of "republicanism" - all people are equals whatever their color, origin or religion - explains to a certain extent why "France is a bit uneasy with cultural diversity" (Fulchiron 2010, 613). This abstract way of considering people makes the issue of "diversity" quite a taboo in France with a flavor that is not quite the same in Belgium. However, this difference regarding structural dimensions between the two countries is not correlated, in our observations, with significant differences or recurring patterns in the interactions at the level of the courtrooms.

In the absence of formal cultural experts provided by legal provisions or by practical judges' choices, we have decided to address the reality of the legislative announcement of "family pluralism" through the observation of daily life in the courtrooms grasped by our respective and sometimes disconnected fieldworks.

\section{Fieldwork and methodology}

Our individual and collective research projects have conducted the three of us to feed and progressively build a common study on the diversity of forms taken by cultural and ethnic elements in the field of family justice in Belgium (Simon 2015, Simon \& Truffin 2016, Wyvekens 2013) but also in France (Wyvekens 2017, 2016, 2014). The core of our fieldwork is constituted by extensive observations of different types of family justice hearings, recorded or transcribed in detailed way. In these judicial settings, we paid attention to implicit scripts and patterns of interactions and to the types of information exchanged between the participants according to their status. It also relies on a careful reading and transcription of the court files and all the documents they can contain, including the judgements. All these informations allowed us to 'reconstruct' cases in order to highlight the kind of cultural elements and their place in the judicial trajectories of 'families with a migrant background'.

By 'family with a migrant background' we refer to family in which one or both parties have migrated to Belgium or France or still have close bounds with a foreign state (they still have family in the country where their own parents came from, speak its language, go there for holidays, etc.). Families belonging to this category were determined on the basis of the court file, which usually contains birth certificates or population registers, documents or other information on the family life and situation that makes it possible to identify them as family with a migrant background. Some exchanges during the hearing have also allowed, in certain cases, to establish it.

As we explained in the previous section, the 'cultural elements' we were looking for were not predefined in a static conception. Instead of relying on a monosemic and immutable conception of what 'culture' entails, we analytically assume a dynamic conception of culture as a process "permanently produced, reproduced, negotiated, and oriented to by members of various social settings" (Dupret 2007, 305) in order to account for backgrounds representations and categorizations in line or not with this conception. Our goal was thus to understand how elements were presented especially regarding underlying assumptions about causal relationships between norms and facts. We were thus interested in cultural elements of the everyday life and justice : language skills, family organization, migration experiences, links 
with the country of origin, etc. All these elements are as many empirical gateways to unravel how culture and ethnicity are addressed in the daily family justice process.

Our different fieldworks also combine interviews with professional judges, clarifying their perceptions of 'cultural diversity' and its importance in hearings and decision-making process. These interviews also allowed us to understand how family judges in Belgium and France organize their caseload and how they perceive their decisional power. Interviews with other professionals - attorneys, social workers - and litigants were also conducted in order to integrate in our analysis differentiated perceptions. The content of these interviews is however less used here, as we rather concentrate on what we have observed in order to be consistent with the praxeological commitment mentioned above.

In Belgium, our empirical observations were conducted in 2012 and 2013 in an urban based Youth Court - a section of the Court of First Instance (tribunal de première instance, section jeunesse) - to which numerous family matters were attributed, prefiguring the installment of Family Court (tribunal de la famille) created by a Bill of 30 July $2013^{1}$. Additionally, we have observed how Justice of the Peace (juges de paix) ${ }^{2}$, working in local courts situated in ethnonationally highly diverse urban areas, did conduct their hearings on the basis of Art. 223 of the Civil Code. These hearings have been observed from 2009 to 2013, since in 2014 cases of conjugal separation were legally transferred to Family Courts in an attempt to centralize all family cases in a unique jurisdiction.

Both the hearings based on Art. 223 of the Civil Code and the hearings of the Youth Court regarding issues of civil separation, divorce, legal and physical custody of the children and alimonies offer a relevant and rich empirical material in order to better understand family justice in action. They are indeed all characterized by the wide decision power legally granted to professional judges and the historical evolution towards a "destandardization" of family regulation it paradoxically encompasses, as we have explained in the previous section.

Among the 31 hearings observed in the Youth Court, Caroline Simon selected 30 study cases for which it was possible to access the entire procedural files and decisions ruled by the judges. During the 22 hearings observed in Justice of the Peace Courts by Barbara Truffin and Caroline Simon, 83 cases concerning families with a migrant background were adjudicated and integrated to the present study even though we were not able to access all the judicial files. As already mentioned, this material was completed by semi-directive interviews with numerous actors taking part in family justice. This includes judges and attorneys and other "experts" such as social workers, but also lay persons as litigants with a migrant background.

In France, Anne Wyvekens observed about 40 hearings in two Family Courts, both in ethnonationally highly diverse urban areas: one in the Paris region, the other in the South-Eastern part of the country. They included litigation about civil separations, divorces, annulments of marriage, children alimonies, legal and physical custody as well as visitation rights. In addition, she conducted a set of interviews with family Judges. This fieldwork took place from 2010 to 2014. A previous study also consisted in interviews with different kinds of judges, both in

\footnotetext{
${ }^{1}$ Loi belge du 30 juillet 2013 portant création d'un tribunal de la famille et de la jeunesse, Moniteur Belge, 27 septembre 2013.

2 The juge de paix - literally translated by Justice of the Peace - in Belgium is a professional and local judge in charge of small civil cases. He was in charge of specific familial cases including civil separation before divorce until September 2013 when this competence was transferred to the new Family Court.
} 
Belgium and in France, in order to get a more general, exploratory view of the way they perceived the issue of "cultural diversity".

All the fieldworks were conducted before the terrorist attacks. They therefore do not include the reactions they have triggered in the discussion of Islamic normativities in Belgian and French family justice.

As already mentioned, cultural elements - whether concerning cultural norms or the factual dimensions of the cases - were exceptional during the hearings we have observed. The paucity of "cultural flavored" discussions varies in extent and quality according to the different roles or status taken by the participants in the interactions.

\section{Cultural and religious norms evoked by litigants}

To begin with, it should be underlined that the most exceptional figure in our material is when a litigant "dare" to evoke explicitly a cultural or a religious norm related to migrant background in a family conflict, in order to be recognized or simply taken into account in the decisionmaking process. This first figure has to be distinguished - according to our understanding of the kind of cultural elements we have chosen to concentrate upon - from international private law discussions about foreign family law dispositions. The latter are and remain "legal" and connected to state-based justice systems. What we explore here are explicit normative statements that do not find their source of authority in a foreign state legal system, but are presented as part of a set of cultural or religious principles that give them their definitive and persuasive character (Comaroff \& Roberts 1981, 262; Greenhouse 1985, 100-101).

In our material, there were very few cases of this type in which the parties expressly invoke a cultural or religious norm in support of their application. Two types of applications specifically belong to it: applications for minor's marriage authorization and for marriage annulment. The first ones were observed in two cases brought before a Belgian Youth Court (in front of the same judge). The parties were claiming the application of a Belgian legal norm that allows the Court to lift the ban to marry before the age of 18 for 'serious reasons' on a request of the minor or his/her parents (Art. 145 of the Belgian Civil Code). These claims were clearly linked with Muslim religion which prohibits any sexual intercourse and any cohabitation before religious marriage but also with the state legal requirement to precede religious marriage by civil marriage (Art. 21 of the Belgian Constitution and Art. 267 of the Belgian Penal Code). In one of the cases, the following discussion took place during the hearing:

"The fiancé: I would just say, we have rules to respect ... There is the Belgian law but we have other rules to respect as we are Muslims, that's why... If she gets pregnant... The Judge [to the minor, we will call Aïcha]: Are you pregnant, Aïcha?

Aïcha: No, but if we want to have a baby, we must be married...

The Prosecutor: But our law is a secular one and ignores religions...

The Judge: I understand that your religion forbids you to have a relationship before marriage but I will have to consider whether this is a serious reason or not..."

In both cases, the religious norm motivating the legal claims was not upheld as a 'serious reason' by the Judge. Both judgements state, in very similar terms, that:

"In the present case, the litigants put forward, as serious grounds, the love feeling between Aïcha and her fiancé, their wish to get married as soon as possible, as well as the reasons 
related to their religious confession, which prevents them from having close relationships, let alone intimacy, before marriage.

The love feeling that binds Aïcha and his fiancé, their desire to live together as soon as possible, to have a family and the respect of the Muslim tradition, are respectable, but do not constitute, according to the Belgian law and more specifically with regard to Art. 145 of the Civil Code, a 'serious reason' that would allow the Youth Court to lift the ban to marry before the age of 18 years".

These cases show a Judge and a Prosecutor that are not keen to consider the religious norm invoked by the litigants as a relevant argument for their claims and thus dismiss it. During the hearings, the religious norm is clearly situated as contradictory to secular legal Belgian norms, as well as balanced - to some extent- against the open legal concept of the best interest of the child, mentioning the risk that girls will not finish their studies, for example. But this assessment does not appear in the judgment, which limits itself to note that love and tradition cannot be recognized as sufficient reasons for marriage authorization.

The cases of marriage annulment are usually ruled the same way. During our interviews, several family judges explained that requests for marriage annulment can be "cultural': some spouses request annulment instead of divorce in order to see their marriage completely erased, as a way to keep the "virginity", culturally or religiously needed to marry another time. In such cases, the cultural norm is more often than not dismissed by the judge, based on a strict enforcement of the legal conditions of annulment. Yet we have found one decision of a French Family Court which explicitly admitted it and recognized it. The motivation is interesting insofar it mixes legal and cultural arguments. The annulment is based on Art. 184 of the French Civil Code and a lack of consent since the spouses had undergone "family and cultural pressure". At the same time, the ruling explicitly mentions that the spouses had chosen to ask annulment because it was the request which was "closer to their traditions and their culture". In this case, a "virginity certificate" had been produced in order to prove that the marriage had not been consummated.

These cases involve a normative understanding of culture, as we have explained it in the first section. This normative understanding does not appear problematic as such, because it seems in line with the conception endorsed both by the litigants and - in his/her turn - by the judge who has to decide the case. Even if no legal rule provides guidelines according to which the judge could consider these cultural norms as pertinent elements in ruling the case, the fact that both litigants and judges consider the cultural element as a norm rather than a fact, a norm the litigants asked to be taken into account, allows the judge to assess these norms in comparison with the norms of the Belgian legal system and to contrast them - often in a conflictual relationship - with the legal rules that the judge must apply. Although the reasoning behind the decision may appear insufficient, it remains that the assessment of a claim seeking to give an effect to a cultural or religious norm in the light of the legal norms concerned, seems adequate regarding the judges' mission. Other cases appear more problematic as they show a gap between the way cultural elements are framed by the litigants and the way the judge apprehends them.

\section{Cultural facts raised by litigants vs. normative understanding of the Judges}

Cases in which culture can be clearly grasped under a normative conception are infrequent. More often than not, what should or could be labeled as cultural norms or facts remains unclear and uneasy to unpack. There is a multiplicity of forms and a complexity in the significance which the cultural elements can take in the exercise of family justice. 
The case we propose to analyze here is representative of these multiples incongruous ways of understanding cultural elements. In this affair, two grandparents (both born in the Democratic Republic of the Congo) filed a lawsuit in the civil chamber of Juvenile Court against their son (born in Belgium) and his wife (born in Burundi); they asked for the recognition of the grandparents' right to personal relationships with their three grandchildren on the basis of Art. 375 bis of the Belgian Civil Code ${ }^{3}$.

The context of the disputes between the grandparents and the parents, as documented in the procedural written pieces but also during the interactions of the hearing, appeared to have started with a major conjugal crisis in the parental couple in 2006. This crisis led the young mother to leave the marital residence which she nevertheless returned to, a few weeks later, after reconciliation with her husband. If the stepparents did not oppose her returning to the marital home, they asked the Congolese custom to be respected. In other words, they wanted their daughter-in-law to perform the rituals necessary for the restoration of trust, that is to say, the organization of a large meal with the extended family and the payment of a sum of money to the husband's parents in order to compensate for the dishonor inflicted upon the whole family during their separation.

The daughter-in-law refused to perform the ritual, arguing that the couple's affairs were private, that the issue was between her and her husband and that it should be resolved without the involvement of her husband's family. Since then, relations between the couple and the rest of the family were tensed and progressively shattered. The daughter-in-law was not welcome any more at her stepparents' home. Conversely, the son and his wife did not allow their children to spend time with their paternal grandparents since the latter would not open their door to their daughter-in-law.

At one point of the hearing, the judge - which was obviously trying to assess the interest of the children - asked to the grandparents: "In your living room, is there room only for your grandchildren, or is there also a place for your son and his wife?" After a pregnant silence, the grandfather explained at length that it was thanks to his intervention and respect for Congolese customs that his son and his daughter-in-law were still together at the time of the trial. During the crisis in 2006, he stated, it was he who had done everything to encourage them to return to each other, while his son's wife had not respected the simple customary principle of restoration. Nevertheless, the grandfather argued, they had contracted a customary marriage under Congolese custom in which they had pledged to respect the traditions, and since his son's wife had honored neither customs nor the customary wedding, she could not return to the grandparents' home. The daughter-in-law replied that she had always done everything possible to maintain a good relationship with her husband's parents, but that they continued rejecting her and that the couple's crisis in 2006 did not concern them.

After having closed the hearing and being back to her office, the judge said:

"I cannot accept that the grandparents reject the mother. [...] Well, I do not mind taking diversity into account, but there is a limit: I rule according to Belgian family law and I know nothing about Congolese culture, so I cannot decide on it! I cannot accept it under Belgian law. And if the mother does not want to submit to the custom, she is within her right to do so!"

\footnotetext{
${ }^{3}$ It reads as follows: "Grandparents have the right to maintain personal relations with the child, as does any other person who justifies a special emotional connection with him. In the event of disagreement, the exercise of this right is determined by the Court at the request of the parties or the public prosecutor, in the interest of the child".
} 
This extract shows how the judge interpreted and responded to the invocation of the customary rite: the judge took it as if the grandparents had asked to recognize it and therefore dismissed it. In the prolongation of this comment, her decision did actually reject the grandparents' application:

"The plaintiffs required from their daughter-in-law the respect of a Congolese customary rite. The defendants refused to do so. Given this, whereas their son (...) and grandchildren are always welcome at their home, the grandparents not only refuse to let their daughterin-law enter their home, they also deny her status as a wife and mother. Under these conditions, the interests of the three children would not be met at the grandparents' home as they would speak and even behave in a way that would show that they refuse to respect the person of the mother. In doing so, the grandparents, the plaintiffs, would undermine respect for parental authority in this case. Therefore, the lawsuit was judged to be unfounded and is dismissed."

This orientation of the judge might be problematic if we consider that in explaining the causes of the conflict (cultural facts) the grandparents were not automatically asking the judge to confirm the legitimacy or to recognize the validity of the custom. In refusing legal relevance to customary norms and affirming the right of the mother to resist it, under Belgian law, the judge somehow reduces the scope of discussion of the "best interest of the children" according to a normative understanding of what culture entails here.

But if we take the cultural elements of the case as pertinent facts instead of a customary norm, the question that the judge would have to address is no longer about the (mis)recognition of the Congolese custom but about the arguments at stake concerning the interest of the children to maintain personal relationships with their grandparents. In the discussions, there were clearly two kinds of conception of such interest. On the one hand, the grandparents were seeking to mobilize the interest of the children to be included in the wider family, as a community called to structure the relationships between individuals. Likewise, the grandparents' counsel particularly stressed the importance of the grandchildren being integrated into a larger family, with their uncles, aunts and cousins. The argument of their daughter-in-law, on the other hand, referred to individual interest and the right to privacy of the nuclear family, values that are more commonly associated with contemporary Western societies.

In linking her ruling to the question of the respect of the Congolese custom instead of assessing where the best interest for the children lies between two conceptions of the family, it appears that the judge misunderstood what was at stake in the claim of the grand-parents. It also led her to immediately take the side of the mother and the liberal family model, leaving aside all questions about the possible coexistence of different systems and the values vested in the conception of the grandparents. She fundamentally slips into a hierarchical normative assessment instead of weighing both sides in a determined context. In her reasoning, the best interest of the child standard is established as normatively corresponding with the respect of the mother. It might well be so, but here it is striking that such "interest" is not adjudicated against others. Shortcuts of this kind in the assessment of the interests of the children might well by caused, at least in part, by a normative apprehension of the cultural element of the case and its (almost automatic) dismissal. As a matter of fact, what our empirical material illustrates here is the difficulty for the judges (and other legal professionals) to operate with a more "factually" based definition of culture in order to read and conceive "cultural aspects" as arrangement of facts instead of "rule oriented bodies". In our case, the fact that the conflict originated in relation 
with the customary (disputed) norms was actually "turned" against the plaintiffs by the judge. In her perspective, customary norms could not be legally recognized at all; her reasoning was therefore oriented as if the plaintiffs had used family justice to ratify a customary-made decision. Regretfully, the custom being dismissed, no other dimensions of the case were discussed which led to an impoverished discussion of the interests of the children.

Our point here is to highlight that from the vantage point of the litigants, cultural explanations do not "pay well" in the family justice courtrooms. To invoke a cultural argument or background is not strategically the best option for a plaintiff and can lead to a mismatching in the way cultural elements are tackled in court. This analysis is symmetrically corroborated by a much higher proportion of "culturalization" or ethnic assignations occurring between litigants during the hearings.

\section{Assignations and culturalization by litigants... and judges}

The much common figure in the litigants' discourse is the reference to a supposed religious or ethnic background of other litigants. These cultural elements can be brought as pertinent facts by the litigants. Yet the most frequent kind of reaction by judges is indifference. We could even talk, sometimes, about blindness. It was the case, for instance, in a family hearing in France. A father, native of the Ivory Coast, filed for principal custody of his son. He was worried: the child says his mother calls him an "unblessed child" and he reported that his son was traumatized. The judge seemed not having even heard those words. She only noted that the request was not complete and advised the father to go to the Youth Court. In another case of divorce, the wife claimed that her husband was being islamically radicalized and that his family forced her to consult a marabout. Her husband denied everything. And there was not a word about religion in the decision.

Cultural elements can also appear in social investigation or psychiatric expertise, as facts that are likely to shed light on the situations under scrutiny. But the answer or even the attention they receive from the judge appear highly unpredictable. In a lot of cases, they are simply ignored during the hearings as much as in the judgment. Sometimes, they are brought up in the scene or in the decision. For example, a Guinean couple appeared before a family judge in France. The father had requested his daughters' custody and exclusive parental authority. According to his attorney they would have suffered female genital mutilation when living at their mother's home. A social investigation has been ordered by the judge. The report mentioned the issue of female genital mutilation as one point of disagreement among others between the parents. The mother denied everything, the report said, stating the girls had refused to be medically examined. The report concluded by recommending that the daughters remained living with their mother. We ignore which decision was taken by the judge.

If these kinds of elements can be brought as 'neutral facts' by litigants, they can also, in a lot of cases, mobilize stereotypes and mechanisms of identity assignation. They are often powerful meanings used in order to devaluate the other litigant and - consequently - appear more reasonable or somehow "civilized" than him/her.

During a hearing at the Justice of the Peace Court on civil separation, a Moroccan woman claimed that her husband - present in the room - had reproached her to have brought their problems up to a "miscreant judge". In a case in which a French judge had to rule on custody rights, the mother claimed that her ex-husband was being islamically radicalized and that she had been the victim of religious harassment. Conversely in another case about domestic 
violence in a French Court, the husband declared at the end of the hearing that his wife was now wearing a headscarf and moving in Salafist circles. Here again religious assignation and signs are used to morally portray the other litigant.

In such cases, migrant ethnicity, cultures and religions are framed in negative ways: they are part of the typical moral repertoires and accusations - which might be true and fact-based or not - that are thought to convince the judge to take side. Somehow this use of cultural and ethnic background is much more salient than any in-depth discussions of family organization, trajectories or "style".

Several cases are built on the same scenario: one of the spouses uses "cultural" elements in order to depreciate the other. An old Moroccan woman asking divorce describes at length her life and the way her husband had been treating her. "I have never worked, I cannot speak French, my husband wouldn't let me go outside, he didn't give me any money, and he used to beat me..." The judge interrupts her "This is not the place to explain why you want to divorce". The woman speaks again "I was not allowed to go out, he owns two cars, two houses in Morocco, he used to keep all the money..." The judge interrupts her again: "I know, I know that."

Frequently adopted to respond to accusations and assignations to problematic ethnic or religious identities advanced by one litigant against the other, the indifference of the judge is difficult to interpret. It seems however that this attitude simply expresses a lack of time and means to establish the reality of the accusation. It is not clear for us in which extent this indifference occurs and varies when compared with other moral accusations.

A last and somehow much more problematic figure is the one in which the judge himself introduces the cultural element to "culturalize" the litigants and assigns them to ethnically charged figures of "migrants". During a hearing concerning a conflict between divorced Turkish parents about parental authority and visiting rights of their children, the judge reasserted her decisional power when saying:

"Mister has to stop his threatening text messages. But please, Madam, your family also has to renounce to threatening your ex-husband. I know the ways of certain communities ...with the uncles, aunts and the family.... This is "settling of accounts"! It worked before I arrived, but now that I am here, it has to stop."

In another case, the fact of being an irregular migrant becomes an aggravating factor in the reasoning of the judge in the assessment of the best interest of three children whose legal and physical custody was disputed by their divorced parents, both Russians.

"Mister ... has filed in for principal custody of the three children. The psychological examination is not worrisome inasmuch the children are concerned. However it highlights a disturbed psychological state of mind of their father. We have to keep in mind that Mister ... does not speak a word of French and is quite passive: he still stays at a reception center for asylum seekers with two of the children. All this, despite the fact that he is living in Belgium for years now. Now, he states that he wants to apply for Czech nationality and establish himself in Czech Republic when obtained. The Court would be much more reassured if the custody of the children was attributed to Madam, but she has not asked for this." 
Here, the reasoning heavily relies on a moral evaluation of the administrative status of the father and of what appears to be his failure of integration into Belgian society (precarious housing in a shelter, lack of French language, irregular administrative stay and poorly organized actions to obtain a regularization of his administrative status). The judge mobilizes what he knows about the administrative status of the father; he connects his lack of integration, as it was an incriminating evidence, with his parenting aptitudes. More than operating a simple equation between two figures, the "badly integrated migrant" takes literally over the father's one. From a legal perspective such overdetermination of family law issues by administrative status is quite disturbing. Here again cultural or ethnic backgrounds are heavily charged and morally shortcut proper in-depth assessment of the family situation.

\section{Conclusion}

In documenting the ways in which cultural elements were brought into the script of family justice, our first finding was the lack of "textbook" cultural defense cases or "red handed" cases of cultural diversity in our material. Occurrences where cultural elements were conceived in a normative outlook by the litigants and mobilized to insert or support the cultural dimension of a case were rather an exception. Even when they happened, most of the time judges were ignoring them, or immediately dismissing them as opposing the secular state legal system, which led to an impoverished discussion about cultural norms entering family justice.

Other cases show how the meaning given to cultural elements can be very different from the litigants' point of view and the one of the judges, leading to a misunderstanding between culture as a relevant fact in the contextualization of the case and culture as a norm that litigants supposedly want to be recognized by State justice. Here also, oppositions between the alleged cultural norm and state law systems are blurring the lines of a comprehensive and complex understanding of cultural elements entering family justice.

Several hypotheses of such a paucity in the way cultural elements can be brought and addressed in the day-to-day family justice can be made. Firstly, we would like to point out that the judicial script which implicitly structures family justice is not propitious to the unveiling of elements associated with migrant "cultures". No legal provision considers cultural elements as relevant in the assessment of a case; cultural claims are almost instantly considered in a conflictual relationship with the secular state legal system; presumed equality and agreement's primacy hardly suffer other standards than the deliberative and liberal postulates; time constraints and routinized ways of assessing families' realities do not allow discussing differences in family values. In this perspective and quite logically, the reactions of the judge contain rare acceptance of cultural dimension.

If cultural facts are more often used by litigants in order to explain a situation, cultural elements can also be used in a more essentialized way between litigants with migrant background alluding to negative conception of cultural identities. Litigants with the same migrant background accuse one another to have bad moral qualities attached to barbarian or savage status linked to a common but somehow contested identity ${ }^{4}$. The impact that such 'use' of cultural elements has in the judicial process and on the decision forged by the judges is difficult

\footnotetext{
${ }^{4}$ We observed the same reversal in a criminal case in which the defendant (a young man) and the victim (his wife) were of the same Moroccan origin: the family of the young woman called her husband an archaic person, a savage. (Wyvekens 2014,142).
} 
to measure. But the way in which some judges also mobilized these mechanisms of assignation to reify conceptions of cultural identities raised in its turn a lot of questions.

On an average, judges have vague ideas about cultural features of family diversity and tend to reproduce these stereotypical views. "African people like to solve their problem through discussions, rather than bring up a case to state justice". "Men from North Africa do not easily admit and express regrets about their actions" ... As we have seen, this can lead to or reinforce ethnic assignations of the litigants to "bad" moral identities ("savages"; "poorly integrated foreigners" ...) on behalf of the judges themselves. This tendency might, in turn, encourage the "culturalization" of the adversary used by the litigants as we have seen above.

But other judges are quite aware of this type of risks and biases encompassed in "cultural diversity" and actively seek to train themselves: reading, attending training sessions - which exist - at the National French School of the Judiciary and in a lesser extent at the Belgian School of the Judiciary. Each judge becomes his own expert and develops his own expertise. In French we call it "tinkering" ("bricolage"). Cases can also be informally discussed with other judges familiar with one another, but not within official meetings. Finally, whether families have migrant origin or not, judges use the same general tools - social investigation, psychiatric or psychological expertise... - in which cultural elements can appear and be addressed... or not. Therefore they only incidentally bring up elements likely to shed light on cultural dimensions of a situation. Additionally, the result is always unpredictable. They intervene only "by chance", rarely, and their interventions can be more negative than positive when considering general communication.

This common feature for Belgian and French fieldworks in family justice should be compared with other national settings in order to assess the importance of these reified and negative views of migrant ethnic and cultural backgrounds. For us, this should be the first step before assessing the need of cultural expertise, which might otherwise reinforce stereotypical and fixed views of "cultures". Indeed, if socio-legal knowledge has to be inserted in the courtrooms we have observed, it should be aimed at allowing more fluid and dispassionate conceptions of cultural diversity and help to deflate harmful stereotypes and disturbing dual-type of migrant identities.

As we have documented above, judges play a critical role in admitting and/or reinforcing such stereotypes and, at the end of the day, in (not) allowing cultural dimensions to be brought by litigants. The possible role of cultural expertise in these judicial settings could not be envisioned without keeping this in mind. As gatekeepers of the judicial communication, judges might be more systematically trained to help to deflate ethnic assignations instead of reinforcing them. In this regard the most worrisome result of our researches lies in the tendency of some judges to culturalize litigants with migrant backgrounds with damaging consequences as judicial reasoning is concerned.

Our results suggest that assessing the cases without presupposing stable cultural identities and simplistic models of causalities but interrogating the importance of other dimensions than the one directly pertinent for the law might facilitate the communication between the judges and the litigants. However, such training might not be easy to design nor to implement. In a training session in France a young judge and an expert from Malian background engaged in a revealing dialogue on this point. The young judge said: "We have never been taught about all this!" And the Malian "cultural expert" responded: "The problem is, that when you will leave the training, you won't know what to do with it". 


\section{Bibliography}

Bouillier, V. (2011). Interactions entre les institutions judiciaires françaises et les communautés Sri Lankaises : des affaires familiales en cour d'assises en région parisienne. Hommes \& Migrations, 129, 52-61.

Brumann, C. (1999). Writing for Culture: Why a successful concept should not be discarded. Current Anthropology, 40(1), 1-27.

Cardia-Vonèche, L. \& Bastard, B. (2005). Vers un nouvel encadrement de la parentalité ? Informations sociales, 122(2) : 110-21.

Colemans, J. (2015). Ce que les émotions font faire aux professionnels du droit : Jalons pour une approche praxéologique des expressions émotionnelles dans la sphère judiciaire. Social Science Information, 54(4), 525-542.

Comaroff, J.L. \& Roberts, S. (1985). Rules an Processes. The cultural logic of dispute in an African context. Chicago (IL) : University of Chicago Press.

Cowan, J.K. (2006). Culture and rights after culture and rights. American Anthropologist. 108(1), 9-24.

Cowan, J.K., Dembour, M.-B. \& Wilson, R. (Eds) (2001). Culture and rights: Anthropological Perspectives. Cambridge, UK: Cambridge University Press.

Cuche, D. (2016). La notion de culture dans les sciences sociales. Paris, France : La Découverte.

de Singly, F. (2010). Sociologie de la famille contemporaine. Paris, France: A. Colin.

D'hondt, S. (2010). The cultural defense as courtroom drama: the enactment of identity, sameness, and difference in criminal trial discourse. Law \& Social Inquiry, 35(1), 67- 98.

D'hondt, S. (2009). Others on trial : the construction of otherness in Belgian first instance criminal hearings. Journal of Pragmatics, 41(4), 806-828.

D'hondt, S. \& Beyens, K. (2004). Interculturele comunicatie in rechtbanken. Brussels, Belgium : Politeia.

Dupret, B. (2010). Droit et sciences sociales. Pour une respécification praxéologique. Droit et société. 75(2), 315-335.

Dupret, B. (2007). Legal Pluralism, Plurality of Laws, and Legal Practices: Theories, Critiques, and Praxiological Re-Specification. European Journal of Legal Studies, 1, 296-318. http://www.ejls.eu/1/14UK.pdf.

Dupret, B. (2006). Le jugement en action : ethnométhodologie du droit, de la morale et de la justice en Egypte. Genève, Switzerland : Droz-CEDEJ 
Fulchiron, H. (2010). The French Family Judge Encounters Cultural Pluralism. In M.-C. Foblets, J.-F. Gaudreault-DesBiens \& A. Dundes Renteln (Eds.), Cultural Diversity and the Law. State Responses from Around the World (pp.613-633). Brussels, Belgium: Bruylant.

Good, A. (2015). Folk Models and the Law. The Journal of Legal Pluralism and Unofficial Law, 47(3), 423-437.

Greenhouse, C.J. (1985). Mediation : A comparative approach. Man, 20(1), 90-114.

Holden, L. (2011, 2013). Cultural Expertise and Litigation: Patterns, Conflicts Narratives. London, UK: Routledge.

Meulders-Klein, M .-T. \& Théry, I. Eds.(1993). Les recompositions familiales aujourd'hui. Paris, France: Nathan.

Petintseva, O. (2016). Perspectives on 'New' Migrants in Youth Justice. Constitution, Circularity and Effects of Institutional Discourse on Roma and Caucasian Youth, PhD diss., Universiteit Gent.

Ronfani, P. (1997). La déjudiciarisation du contentieux familial. In M.-T. Meulders-Klein (Ed.) Famille \& Justice. Justice civile et évolution du contentieux familial en droit comparé: actes du congrès international (pp. 43-59). Bruxelles, Belgium: Bruylant / L.G.D.J.

Roussel, L. (1989). La famille incertaine: essai. Paris, France: Odile Jacob.

Roy, O. Ed. (2012). Réflexions sur le pluralisme familial. Nanterre, France: Presses universitaires de Paris Ouest.

Simon, C. (2015). The 'Best Interest of the Child' in a multicultural context : a case study. The Journal of Legal Pluralism and Unofficial Law, (47 :2), 175-189.

Simon, C. \& Truffin, B (2016). La diversité culturelle en procès : l'expérience de la justice belge par les familles à composante migratoire, quels enjeux pour le pluralisme juridique ? Anthropologie et sociétés, (2), 107-129

Terrio, S.J. (2009). Judging Mohammed : juvenile delinquincy, immigration and exclusion at Paris Palace of Justice. Stanford : Stanford University Press.

Théry, I. (1998). Couple, filiation et parenté aujourd'hui : le droit face aux mutations de la famille et de la vie privée. Paris, France : Odile Jacob.

Travers, M.H. (2001). Ethnomethodology, Conversation Analysis and Law. Droit et Société, 48, 349-366.

van Rossum, W. (2010). The clash of legal cultures over the 'best interest of the child' principle in cases of international parental child abduction. Utrecht Law Review, 6(2), 33-35.

van Rossum, W. \& Jansen Fredriksen, K. (2014). How legal professionals in the Netherlands 
and in Norway deal with cultural diversity (and ho wit affects social citizenship). In H. Sinding Aasen et al. (Eds.), Juridification and Social Citizenship in Welfare State (pp. 221-240). Cheltenham, UK: Edward Elgar.

van Rossum, W. \& van den Hoven, M. (2016). Paucity and the need for value sensitivity in dealing with youth care : why legal and youth professionals should take cultural and religious considerations seriously. Utrecht Law Review, 12(2), 7-23.

Wyvekens, A. (2017). La justice pénale face à la "diversité culturelle" : la diversité culturelle en question. Revue de Droit Pénal et de Criminologie, 887-906.

Wyvekens. A. (2016). Justice familiale et migration : de la diversité culturelle à la double appurtenance. Recherches familiales, 13, 65-77.

Wyvekens, A. (2014). La justice et la "diversité culturelle" : "les yeux grands fermés"?. Archives de politique criminelle, 36, 123-146.

Wyvekens, A. (2013). Les magistrats et la diversité culturelle : “Comme M. Jourdain”... Les Cahiers de la justice, 3, 139-151. 